\title{
O bem comum em Miroslav Volf
}

\author{
Wallace Soares da $\mathrm{Cruz}^{1}$ \\ Claudete Beise Ulrich ${ }^{2}$
}

VOLF, Miroslav. Uma fé pública: Como o cristão pode contribuir para o bem comum. São Paulo: Mundo Cristão, 2018. 203 p.

O livro Uma fé pública: Como o cristão pode contribuir para o bem comum, de Miroslav Volf, publicado pela Editora Mundo Cristão, representa uma grande contribuição para a comunidade teológica brasileira. Como há pouco material desse importante teólogo disponível em língua portuguesa, o lançamento do livro ajuda a preencher essa lacuna, oferecendo uma obra de um dos teólogos contemporâneos mais proeminentes do Cristianismo Ocidental.

Volf é um renomado teólogo cristão nascido na Croácia. Ele iniciou seus estudos em Filosofia, Grego clássico e Teologia na Universidade de Zagreb e, depois, concluiu o seu doutorado na universidade de Tübingen, na Alemanha sob a orientação de Jürgen Moltmann. Atualmente é professor de Teologia e diretor do Centro de Fé e Cultura da Universidade de Yale, nos EUA. Volf escreveu mais de vinte livros e dois deles foram publicados no Brasil: O fim da memória: Interrompendo o ciclo destrutivo das lembranças dolorosas (2009) e Uma fé pública: Como o cristão pode contribuir para o bem comum (2018). São funções acadêmicas de destaque e produções teológicas de prestígio que enfatizam a relevância desse autor para a comunidade teológica no Brasil.

Volf é uma das personagens centrais nas questões do crescente secularismo cada vez mais presente no âmbito político. Ele sistematiza os impactos da presença cristã num mundo cada vez mais secularizado e seu objetivo é promover a participação dos cristãos na construção do

1 Mestrando em Ciências das Religiões pela Faculdade Unida de Vitória.

2 Doutora em Teologia, professora da Faculdade Unida de Vitória na graduação e pósgraduação. Coordenadora da Cátedra de Teologia Pública e Estudos da Religião. 
bem comum. Volf contribui para o debate sobre as implicações da tolerância e da liberdade religiosa no ambiente polarizado característico da atualidade. Ele aponta para a busca do diálogo entre perspectivas seculares e religiosas, pois, para ele, uma alternativa para lidar com o problema é concentrar-se nos recursos internos de cada perspectiva para o fomento da cultura da paz. A fé cristã deve ser atuante em todas as esferas da vida.

Volf dialoga com fontes da teologia e filosofia clássicas e a partir dessa base entra no debate contemporâneo com suas propostas teológicas. A procura pelo "amor" em Agostinho torna plausível sua reflexão, pois segundo ele o próprio âmago da fé cristã é pautado pelo amor. Os cristãos deveriam amar as pessoas em qualquer circunstância. Um amor traduzido em benevolência, em que pesem discordâncias e desaprovações. De acordo com Volf, essa é a postura amorosa adequada do cristão para participar do debate público em prol do bem comum. Neste sentido, os seguidores de Cristo trabalham visando à prosperidade humana. Todavia, o modo como esse trabalho é feito não pode ser a imposição da própria visão de prosperidade humana e bem comum sobre as pessoas, mas como testemunhas de Cristo, que personifica a vida boa para todos e todas, pois "uma fé que visa se impor e impor seus métodos a outros por meio de qualquer forma de coerção - é também uma fé com falhas graves"3.

Volf se torna indispensável para a reflexão do Cristianismo hodierno. Ele busca mapear uma "alternativa à saturação totalitária da vida pública com uma única religião bem como à exclusão secular de todas as religiões da vida pública"4. Ele não pretende condenar o secularismo, ao contrário, mostra que ao excluir da religião da tomada de decisões e ao impor separação total entre Estado e Igreja, somente o secularismo é favorecido. Isso representa uma injustiça contra as pessoas que aderem a alguma religião, especialmente num contexto em que a fé ganha cada vez mais destaque no debate social. Da mesma forma, seria injusta a imposição de uma fé única para todas as pessoas no ambiente polarizado da atualidade. Volf apresenta uma visão do papel do cristão na vida pública

\footnotetext{
3 VOLF, 2018, p. 16.

4 VOLF, 2018, p. 14.
} 
que evite os perigos tanto da exclusão da religião como da saturação religiosa.

Para Volf, uma interpretação plausível da fé cristã deve se opor ao totalitarismo religioso e apoiar o pluralismo como um projeto político. Desta forma, os cristãos deveriam "inserir-se como uma voz entre muitas na vida pública para promover sua própria visão da prosperidade humana e servir ao bem comum" 5 . Para ele, é indispensável à participação do cristão ou qualquer outro grupo religioso no debate público com as próprias visões sobre a prosperidade humana. Ou seja, oferecer alternativas e contribuições a partir das próprias convicções religiosas. Neste sentido, uma das maiores contribuições da fé cristã pode trazer para o debate público é uma visão da prosperidade humana e do bem comum.

Para Volf, o papel profético das comunidades cristãs é o seu engajamento no mundo. Os cristãos se engajam em todos os aspectos de sua vida para promover a prosperidade humana e servir ao bem comum. Esse engajamento também afeta todas as dimensões de uma cultura, mas não intenta transformar nenhuma delas totalmente. Ou seja, a visão adequada dos cristãos em relação à cultura mais ampla não pode ser a de oposição sem tréguas ou a da transformação total, mas requer-se " uma atitude muito mais complexa: a de tomar os vários elementos de uma cultura internamente diferenciada e em constante mutação [...] aprender com

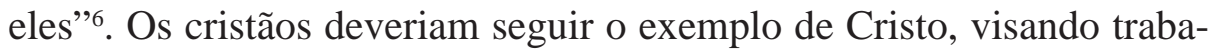
lhar para a prosperidade humana e bem comum sem a preocupação de impor sua visão de mundo. A fé cristã deve ser apresentada como uma dádiva e não imposta como uma lei.

O exemplo de Cristo exige que os cristãos dispensem a outras comunidades religiosas os mesmos direitos e liberdades políticas e religiosas que reivindicam para si. Neste sentido, o pluralismo religioso deveria ser tomado como projeto político, seguindo a ordem de Cristo de em tudo fazer aos outros o que se deseja para si mesmo. Para Volf, o Cristianismo deve ser encarado como um estilo de vida centrado em Cristo e não como um grupo religioso isolado das outras comunidades religiosas. O livro encerra com uma pergunta em aberto que envolve

5 VOLF, 2018, p. 171

${ }^{6}$ VOLF, 2018, p. 16. 
há um robusto debate sobre a questão: "O que constitui uma vida digna de ser chamada boa?"7.

O livro de Volf, além de oferecer uma reflexão adequada para a atualidade, é uma porta de entrada ao debate teológico nacional e internacional. Mesmo sendo pouco conhecido e debatido no Brasil, Volf apresenta propostas teológicas muito relevantes e pertinentes ao contexto brasileiro. E, para aqueles/as que desejam aprofundar, Volf pavimenta um caminho de possibilidades para futuras pesquisas sobre o significado do bem comum, como parte da discussão da práxis teológica, com uma dimensão pública, plural e cidadã.

\footnotetext{
7 VOLF, 2018, p. 171.
} 